\title{
Chapter
}

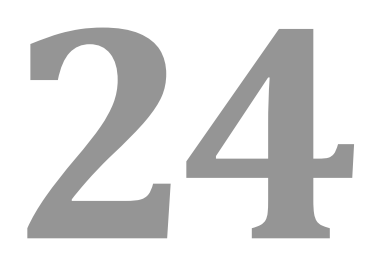

\section{SAFETY ISSUE OF NANOPARTICLES WHICH ARE USED FOR STEM CELL LABELLING AND TRACKING}

\section{You-Kang Chang ${ }^{1,2}$ and Oscar K. Lee ${ }^{3,4,5,6, *}$}

${ }^{1}$ Department of Radiation Oncology, Taipei Tzu Chi Hospital, New Taipei City, Taiwan

${ }^{2}$ School of Medicine, Tzu Chi University, Hualien, Taiwan

${ }^{3}$ Institute of Clinical Medicine, National Yang-Ming University, Taipei,

Taiwan

${ }^{4}$ Taipei City Hospital, Taipei, Taiwan

${ }^{5}$ Stem Cell Research Center, National Yang-Ming University, Taipei, Taiwan

${ }^{6}$ Department of Medical Research, Taipei Veterans General Hospital, Taipei, Taiwan 


\section{Contents}

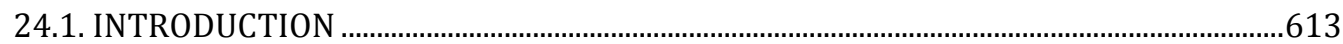

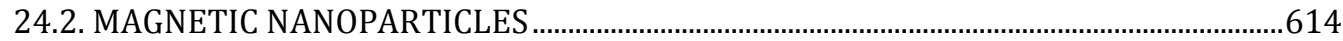

24.2.1. Superparamagnetic iron oxide nanoparticles ......................................................614

24.2.2. Gadolinium oxide nanoparticles................................................................................616

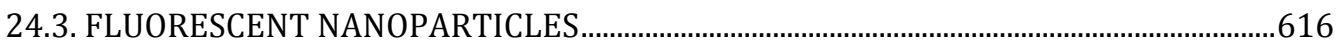

24.3.1. Fluorescent polymer nanoparticles .........................................................................616

24.3.2. Quantum dots.............................................................................................................617

24.3.3. Fluorescent silica nanoparticles ...............................................................................618

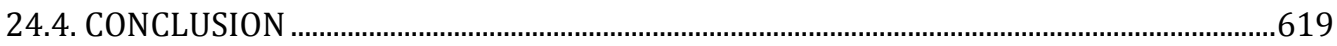

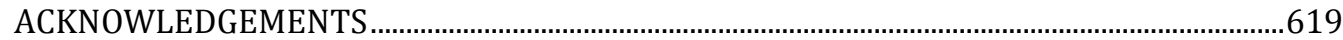

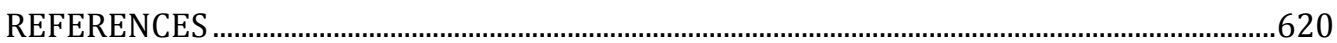




\subsection{INTRODUCTION}

Various kinds of nanoparticles (NPs) have been used for the labelling and tracking of stem cells to determine their destinations and final differentiated fates after transplantation. Ideally, NPs should be biodegradable, non-toxic to stem cells, and should not disturb their multilineage differentiation potential. NPs should give a strong signal, allowing good visualisation of the stem cells. Moreover, the labelling of cells with NPs should be uncomplicated and imaging can be done in vivo in a non-invasive manner. The NPs should not induce adverse or immune reactions in the human body after the transplantation of labelled stem cells. The development of novel NPs is exciting; however, the safety issue should not be neglected. This review will therefore focus on this growing aspect of current NPs and the safety issue of stem cell labelling. Toxicity reports of common nanoparticles are selected and summarized in Table 1. The details of each report will be discussed in the following paragraphs of this review.

Table 1. Common nanoparticles and selected toxicity reports on various kinds of cell lines, stem cells, and animal models

\begin{tabular}{|c|c|c|}
\hline Nanoparticles & Selected toxicity reports & Ref. \\
\hline \multirow[t]{6}{*}{$\begin{array}{l}\text { Superparamagnetic } \\
\text { iron oxide } \\
\text { nanoparticles } \\
\end{array}$} & $\begin{array}{c}\text { Aggravated clinical symptoms in animal model of } \\
\text { labeled MSCs }\end{array}$ & {$[25]$} \\
\hline & Impaired chondrogenesis on hMSCs & [23] \\
\hline & $\begin{array}{l}\text { Accelerated hMSC proliferation via diminishing } \\
\text { intracellular } \mathrm{H}_{2} \mathrm{O}_{2} \text { and affected the expression of the } \\
\text { protein regulators of cell cycle }\end{array}$ & [28] \\
\hline & $\begin{array}{l}\text { Inhibitory effect on osteogenic differentiation and } \\
\text { Wnt signaling pathway in hMSCs }\end{array}$ & [29] \\
\hline & $\begin{array}{c}\text { Accelerated hMSC proliferation, altered gene } \\
\text { expression and impaired chondrogenesis and } \\
\text { osteogenesis }\end{array}$ & {$[30]$} \\
\hline & $\begin{array}{c}\text { Oxidative damage to lipids, proteins and DNA; lipid } \\
\text { peroxidation in hMSCs }\end{array}$ & {$[31]$} \\
\hline \multirow[t]{2}{*}{$\begin{array}{l}\text { Gadolinium oxide } \\
\text { nanoparticles }\end{array}$} & $\begin{array}{l}\text { Cytotoxicity and genotoxicity via DNA damage on } \\
\text { human skin fibroblast cell lines }\end{array}$ & [41] \\
\hline & $\begin{array}{c}\text { Necrosis of primary mouse bone marrow stromal } \\
\text { cells via lysosomal rupture and ROS injury }\end{array}$ & [42] \\
\hline $\begin{array}{c}\text { Fluorescent } \\
\text { polymer } \\
\text { nanoparticles }\end{array}$ & $\begin{array}{l}\text { Increase in the IL-8 release in hMSCs and altered gene } \\
\text { expression }\end{array}$ & {$[46]$} \\
\hline
\end{tabular}




\begin{tabular}{ccc}
\hline Nanoparticles & Selected toxicity reports & Ref. \\
\hline Quantum dots & $\begin{array}{c}\text { Apoptosis in mouse blastocysts, inhibited cell } \\
\text { proliferation, early-stage blastocyst death in mouse }\end{array}$ & {$[60]$} \\
\hline & Apoptosis in mouse myoblast cells line & {$[62]$} \\
\hline $\begin{array}{c}\text { Fluorescent silica } \\
\text { nanoparticles }\end{array}$ & $\begin{array}{c}\text { Abnormal morphology and altered gene expression of } \\
\text { obuman neural stem cells }\end{array}$ & {$[67]$} \\
\hline & Cell death at high particle doses in neural stem cells & {$[68]$} \\
\hline & $\begin{array}{c}\text { Enhanced proliferation of human adipose tissue- } \\
\text { derived stem cells through ERK1/2 activation }\end{array}$ & {$[69]$} \\
\hline & $\begin{array}{c}\text { Metabolic stress in hMSCs through EGR1, CCND, and } \\
\text { E2F1 genes }\end{array}$ & {$[70]$} \\
\hline
\end{tabular}

MSC: mesenchymal stem cells; hMSC: human mesenchymal stem cells

\subsection{MAGNETIC NANOPARTICLES}

Magnetic resonance imaging (MRI) is a non-invasive, deep tissue penetrating imaging technique which provides excellent contrast between the different soft tissues of the body, and reconstructs 2D and 3D images of the tissues and organs easily. Magnetic NPs are categorised as T1 or T2 contrast agents for MRI depending on the relaxation processes. Among the magnetic NPs, superparamagnetic iron oxide NPs (SPIOs) and gadolinium oxide NPs are the most popular choices for T2 and T1 MRI-based stem cell labelling and tracking respectively. SPIOs have been widely used for stem cell labelling and tracking.

\subsubsection{Superparamagnetic iron oxide nanoparticles}

SPIOs have been shown to be biocompatible, biodegradable, and non-toxic to different kinds of stem cells as well as having no adverse effects on stem cell phenotypes or differentiation [1-12]. Additionally, several kinds of SPIOs have been used for stem cell labelling and tracking in vivo in MRI [13-16], as well as in clinical applications and animal models [17-22].

However, in 2004, Kostura et al. reported that Feridex (Ferumoxide) labelling of human mesenchymal stem cells (hMSCs) impairs chondrogenesis but does not affect cell viability, proliferation, adipogenesis, or osteogenesis [23]. Although the multilineage differentiation of SPIO-labelled mesenchymal stem cells (MSCs) is not altered in an in vivo rat model, subtle but significant phenotypic alterations are observed following the subcutaneous implantation of labelled MSCs grown on a collagen-GAG scaffold compared to those grown on implanted, unlabelled control scaffolds [24]. Schafer et al. noted that the use of SPIOs for the labelling of MSCs aggravates clinical symptoms in 
experimentally-induced autoimmune encephalomyelitis, while treatment with unlabelled MSC leads to disease amelioration compared to controls [25]. The authors concluded that in vivo application of SPIO-labelled MSC needed to be performed with caution because the cell-derived exposure of iron can lead to disease aggravation. Furthermore, labelling of hMSCs with ferucarbotran had functional effects on hMSCs by decreasing the migration capacity and colony-forming ability of cells [26]. Later, in 2010, both SPIOs and the static magnetic field were identified as independent factors which affect the functional biology of hMSCs [27].

Huang et al. found that ferucarbotran stimulated hMSC proliferation in particle and ionic (free iron, $\mathrm{Fe}$ ) forms via diminishing intracellular $\mathrm{H}_{2} \mathrm{O}_{2}$ and affected the expression of protein regulators of the cell cycle [28]. In a follow-up study, the inhibitory effect of ferucarbotran on osteogenic differentiation and the Wnt signalling pathway in hMSCs was reported [29]. Cell proliferation and viability of labelled hMSCs was found to be increased by amine $\left(\mathrm{NH}_{3}{ }^{+}\right)$-surface-modified SPIOs, and the cell cycle of labelled cells was accelerated [30]. The osteogenic and chondrogenic differentiation potential of hMSCs was impaired or inhibited, while adipogenic potential was preserved. These findings have raised toxicity and other safety concerns in regard to using newly-developed SPIO NPs for stem cell labelling and tracking.

Novotna et al. reported oxidative damage to biological macromolecules in human bone marrow MSCs labelled with iron oxide NPs [31]. An increase of oxidative injury to lipids, proteins and DNA as a consequence of exposure to SPIOs was detected in labelled cells. Particularly, the levels of lipid peroxidation were high and increased further with time, regardless of the type of nanoparticle. Also, Diana et al. found that SPIO loading significantly reduced movement in fetal stem cell populations (human amniotic fluid and chorionic villi stem cells) without increasing the production of reactive oxygen species [32]. Moreover, motility impairment was directly proportional to the amount of loaded SPIOs, while chemoattractant-induced recovery was obtained by increasing serum levels.

On the other hand, long-lasting hypointensive signals in cardiac magnetic resonance were believed to originate from SPIO-engulfed macrophages during long-term stem cell tracking, rather than the transplanted stem cells. Recently, Huang et al. reported that the hypointensive signal of cardiac MRI was primarily caused by extracellular iron particles in the long-term tracking of transplanted swine MSCs after myocardial infarction [33]. Also, 6 months after transplantation, cardiac MRI identified $32(64 \%)$ of the 50 injection sites, where massive Prussian blue-positive iron deposits were detected by pathological examination. However, iron particles were predominantly distributed in the extracellular space, and a minority was distributed within Cluster of Differentiation 68 (CD68)-positive macrophages and other CD68-negative cells. No sex-determining region Y DNA of donor MSCs was detected in the myocardium. The authors suggested that consideration should 
be given to both the false-positive signal and the potential cardiac toxicity of long-standing iron deposits in the heart.

The other limitations of SPIOs are well illustrated in their use of stem cell tracking [34]. For example, SPIO-labelled cells become diluted in a localised site due to cell division, and consequently, the generated image is inevitably weakened. Furthermore, due to the in vivo migration of SPIO-labelled stem cells, the density of cells is considerably reduced over time, again leading to weakening of the MRI signal [35]. On the other hand, SPIO labelling itself cannot determine whether or what the SPIO-labelled stem cell differentiates into, although through the use of combined imaging techniques such as immunohistochemistry and confocal microscopy, the function of the stem cell can be determined [36].

\subsubsection{Gadolinium oxide nanoparticles}

Contrary to T2 agents, which produce hypointensive signals (dark spots) on MRI images, gadolinium-based T1 agents produce bright hyperintensive signals. Gadolinium oxide NPs have been used to label human aortic endothelial cells and T1 enhancement of the internalised NPs was maintained for up to 7 days [37]. Currently, the use of gadolinium oxide NPs in cell tracking is still in the early stages, and they have been used for labelling brain cancer cells [38] and hematopoietic cells [39]. Surface modification of gadolinium oxide NPs with poly(ethylene glycol) (PEG) could increase their biocompatibility [40]. However, terbium-doped gadolinium oxide NPs induced cytotoxicity in a dose-dependent manner and promoted genotoxicity via DNA damage on human skin fibroblast cell lines [41]. Recently, Jin et al. reported that europium-doped $\mathrm{Gd}_{2} \mathrm{O}_{3}$ nanotubes caused the necrosis of primary mouse bone marrow stromal cells through lysosomal rupture and release of cathepsin $B$, and the overproduction of reactive oxygen species (ROS) injury to the mitochondria and DNA [42]. Prior to applying gadolinium oxide NPs in cell labelling and tracking, their effects on stem cell function and differentiation need to be further investigated.

\subsection{FLUORESCENT NANOPARTICLES}

Fluorescence imaging provides high sensitivity, high resolution, and feasibility for the real-time monitoring biological phenomena. Due to low cost and accessibility, fluorescence imaging is widely used in tracking stem cells. The main fluorescent nanoparticle products on the market are fluorescent polymer NPs, quantum dots (QDs) and fluorescent silica NPs.

\subsubsection{Fluorescent polymer nanoparticles}

Due to their biocompatibility and inertness, polystyrene (PS) and polycarbonate are widely used for the production of biomedical devices and 
laboratory equipment. Currently, the most common fluorescent polymer NPs are PS NPs, which are mainly prepared through emulsion polymerisation [43]. Some of the PS NPs are frequently used in phagocytosis assessment of phagocytic cells. Phosphonate-functionalised PS NPs prepared by mini-emulsion polymerisation were incorporated by MSCs, and the cell viability was found to be unaffected [44]. Furthermore, the multi-lineage potential of MSCs was well preserved. PS does not degrade in the cellular environment, so PS NPs usually exhibit no short-term cytotoxicity [45].

Very few reports have addressed the safety issue of PS NPs on stem cell labelling $[46,47]$. Two sets of either bioinert (PS without carboxylic groups on the surface) or biodegradable (poly(L-lactic acid) (PLLA) without magnetite) particles were uptake by hMSCs and hematopoietic stem cells (hHSCs) [46]. Flow cytometry and microscopy analysis showed high uptake rates and no toxicity for all four tested particles in hMSCs and hHSCs. The PLLA-Fe particle showed a significant increase in the interleukin-8 (IL-8) release in hMSCs but not in hHSCs. For hHSCs and hMSCs, multi-lineage differentiation was not influenced by the particles when analysed with lineage-specific clusters of differentiation markers. On the other hand, quantitative polymerase-chain-reaction (qPCR) analysis showed significant changes in the expression of some (but not all) investigated lineage markers for both primary cell types. In another report, conjugated polymer-based water-dispersible NPs were used to label bone marrow-derived rat MSCs successfully and labelled MSCs migrated to the site of injury and retained their labels in an in vivo liver regeneration model [47].

\subsubsection{Quantum dots}

QDs are colloidal, crystalline semiconductor NPs made from II-VI or III-V elements (e.g. PdS, CdSe) [48]. QDs have wide absorption range from ultraviolet (UV) to visible, and are much more resistant (can be up to 100 times) to photochemical degradation than fluorescent dyes, which makes them useful for the long-term tracking of cells and monitoring of biological changes [49]. However, QDs have several inherent problems. First, QDs generally contain toxic heavy metal ions such as $\mathrm{Pd}^{2+}, \mathrm{Se}^{2+}$ and $\mathrm{Cd}^{2+}$. Second, the involvement of dark states and blinking phenomena in QDs requires higher doses to improve the brightness and accuracy of quantitative measurements in cell tracking and imaging [50]. Nonetheless, higher QD doses may raise the signal to noise ratio and result in non-specific binding.

Although QDs have been utilised for stem cell tracking and imaging for many years [51-58], most toxicity and pharmacokinetic studies have focused on the behaviours of II B-VI A and III A-V A QDs in rodents [59]. Investigations of the IV A QDs are still in the early stages. Initial safety and proof of concept studies of one- and two-cell QD-labelled mouse embryos reveal that fluorescent semiconductor nanocrystal QDs are compatible with early mammalian 
embryonic development [51]. In vivo experiments further show that in utero-labelled neural stem and progenitor cells (NSPCs) continue to develop in an apparently normal manner [51]. However, it has been shown that CdSe-core QDs induce apoptosis in mouse blastocysts, inhibit cell proliferation, retard early post-implantation blastocyst development, and increase early-stage blastocyst death in vitro and in vivo [60]. The reproductive and developmental toxicity of manufactured nanomaterials including metallic and metal oxide-based particles, fullerenes (C(60)), carbon black, and luminescent particles has been reviewed in a previous paper [61].

Copper oxide QDs induce apoptosis in mouse myoblast cells line (C2C12) [62]. Further in vivo studies have shown that copper oxide QDs bind to genomic DNA, significantly decrease the viability of cells in culture in a concentration-dependent manner, and inhibit mitochondrial caspases 3 and 7. CdTe QDs, especially those that are smaller in size, resulted in impaired haematopoiesis in an invertebrate model organism, Bombyx mori [63]. QD exposure promoted the mitotic nucleus in prohaemocytes and haematocytes similar to peripheral blood stem cells in humans, but aggravated apoptosis. A decrease in haematopoiesis was accompanied by shrinkage and death of haematopoietic organs via an increase in reactive oxygen species.

According to our review, QDs still have some toxicity or harmful effects on several kinds of stem cells. The lack of studies on animal models using primates and human stem cells also limits our understanding of QDs. Further application of QDs in stem cell labelling and tracking merits further research.

\subsubsection{Fluorescent silica nanoparticles}

There are only a few reports applying fluorescent silica NPs for stem cell labelling and tracking. On the contrary, fluorescent silica NPs produced in research laboratories were widely referred to in publications of non-stem cell labelling and tracking. Cyanine dye-doped silica NPs were reported to directly discriminate live and early-stage apoptotic mesenchymal and embryonic stem cells through a distinct external cell surface distribution [64], which makes them ideal for stem cell labelling and tracking. On the other hand, mesoporous silica NPs are also used for the delivery of growth factors to induce advanced differentiation of transplanted stem cells $[65,66]$.

However, hNSCs aggregated and exhibited abnormal morphology when exposed to silica and titanium oxide NPs [67]. Moreover, all of the particles affected the gene expression of nestin (stem cell marker) and neurofilament heavy polypeptide (NF-H, neuron marker). These results may indicate the potential toxicity of accumulated NPs for long-term usage or continuous exposure. Silica NPs with different [-NH2, $-\mathrm{SH}$ and poly(vinylpyrrolidone) (PVP)] surface modifications cause cell death at high particle doses, except for PVP-coated $\mathrm{SiO}_{2}$ NPs [68]. Among the tested neural tissue-type cells, neural stem cells and astrocytes internalise plain $\mathrm{SiO}_{2}, \mathrm{SiO}_{2}-\mathrm{NH}_{2}$ and $\mathrm{SiO}_{2}-\mathrm{SH} \mathrm{NPs}$, 
while neurons do not take up any NPs at all. Their data indicate that the PVP coat, by lowering the particle-biomolecular component interactions, reduces the biological effects of $\mathrm{SiO}_{2} \mathrm{NPs}$ on the investigated neural cells.

It has been reported that scaffolds containing silica NPs may enhance the proliferation of human adipose tissue-derived stem cells through ERK1/2 activation [69], meaning that single component silica-derived NPs could be useful for bioscaffolds in stem cell therapy. Not surprisingly, silica NPs were found to induce significant metabolic stress in hMSCs in a recent report [70]. Alterations in the cytoplasmic organisation, nuclear morphology, cell cycle progression, and expression of genes linked to cell cycle-dependent metabolic stress through EGR1, CCND, and E2F1 genes, which are the primary indicators of metabolic stress, have been observed. The authors suggest that the acute and chronic toxicity mechanisms of silica NPs should be investigated in greater depth with special reference to food safety.

\subsection{CONCLUSION}

We summarise the toxicity reports of existing or commercial NPs which can act as contrast agents for MRI and fluorescence imaging for stem cell labelling and tracking. Prior to the extensive use of these NPs in stem cell therapy in humans, concerns regarding NPs, including the unclear safety profile, signal loss in long-term tracking, limitation of single modality NPs, viability and ultimate fate of labelled cells, and effects on multilineage differentiation potential will have to be clarified. Careful investigation of the effects of NPs on human stem cells and animal models using primates will facilitate our understanding and should be carried out ahead of the application of novel NPs in clinical trials.

\section{ACKNOWLEDGEMENTS}

This work was supported in part by the UST-UCSD International Center of Excellence in Advanced Bioengineering (Grant Number: MOST103-2911-I-009101) under the Taiwan Ministry of Science and Technology I-RiCE Program. The authors acknowledge financial support from the Ministry of Science and Technology, Taiwan (MOST103-2314-B-010-053-MY3, MOST103-2120-M010-001, and MOST104-2321-B-010-008), the Ministry of Economic Affairs, Taiwan (103-EC-17-A-17-S1-203), as well as the National Yang-Ming University/Cheng Hsin General Hospital Grant (CY10405). This study was also supported by Aiming for the Top University Plan, a grant from Ministry of Education. 


\section{REFERENCES}

1. A.S. Arbab, G.T. Yocum, A.M. Rad, A.Y. Khakoo, V. Fellowes, E.J. Read, J.A. Frank. NMR Biomed. 18(2) (2005) 553-559.

2. D. Choi, J.H. Kim, M. Lim, K.W. Song, S.S. Paik, S.J. Kim, H.J. Cheong, J.S. Jeon, H.S. Park, Y.S. Song, H. Khang, J.H. Won. Tissue Eng. Part C Methods 14(1) (2008) 15-23.

3. A. Focke, S. Schwarz, A. Foerschler, J. Scheibe, J. Milosevic, C. Zimmer, J. Schwarz. Magn. Reson. Med. 60(6) (2008) 1321-1328.

4. A. Heymer, D. Haddad, M. Weber, U. Gbureck, P.M. Jakob, J. Eulert, U. Nöth. Biomaterials 29(10) (2008) 1473-1483.

5. J. Krejci, J. Pacherník, A. Hampl, P. Dvorák. Gen. Physiol. Biophys. 27(3) (2008) 164-173.

6. Z. Li, Y. Suzuki, M. Huang, F. Cao, X. Xie, A.J. Connolly, P.C. Yang, J.C.Wu. Stem Cells 26(4) (2008) 864-873.

7. K.W. Au, S.Y. Liao, Y.K. Lee, W.H. Lai, K.M. Ng, Y.C. Chan, M.C. Yip, C.Y. Ho, E.X. Wu, R.A. Li, C.W. Siu, H.F. Tse. Biochem. Biophys. Res. Commun. 379(4) (2009) 898-903.

8. L.Wang, J. Deng, J. Wang, B. Xiang, T. Yang, M. Gruwel, T. Kashour, B. Tomanek, R. Summer, D. Freed, D.S. Jassal, G. Dai, M. Glogowski, R. Deslauriers, R.C. Arora, G.Tian. Magn. Reson. Med. 27(1) (2009) 108-119.

9. A. Crabbe, C. Vandeputte, T. Dresselaers, A.A. Sacido, J.M. Verdugo, J. Eyckmans, F.P. Luyten, K. Van Laere, C.M. Verfaillie, U. Himmelreich. Cell Transplantation 19 (2010) 919-936.

10. V.K. Verma, S.R. Kamaraju, R. Kancherla, L.K. Kona, S.S. Beevi, T. Debnath, S.P. Usha, R. Vadapalli, A.S. Arbab, L.K. Chelluri. Int. J. Nanomed. 10 (2015) 711-726.

11. X.X. Li, K.A. Li, J.B. Qin, K.C. Ye, X.R. Yang, W.M. Li, Q.S. Xie, M.E. Jiang, G.X. Zhang, X.W. Lu. Int. J. Nanomed. 8 (2013) 1063-1073.

12. M.R. Pickard, P. Barraud, D.M. Chari. Biomaterials 32(9) (2011) 2274-2284.

13. P.W. So, T. Kalber, D. Hunt, M. Farquharson, A. Al-Ebraheem, H.G. Parkes, R. Simon, J.D. Bell. Cell Transplantation 19(4) (2010) 419-429.

14. B. Zhou, H. Shan, D. Li, Z.B. Jiang, J.S. Qian, K.S. Zhu, M.S. Huang, X.C. Meng. Magn. Reson. Med. 28(3) (2010) 394-399.

15. J.H. Lee, M.J. Jung, Y.H. Hwang, Y.J. Lee, S. Lee, D.Y. Lee, H. Shin. Biomaterials 33(19) (2012) 4861-4871.

16. J. Han, B. Kim, J.Y. Shin, S. Ryu, M. Noh, J. Woo, J.S. Park, Y. Lee, N. Lee, T. Hyeon, D. Choi, and B.S. Kim. ACS Nano 9(3) (2015) 2805-2819.

17. K. Hekimoglu, Y. Ustundag, A. Dusak, B. Kalaycioglu, H. Besir, H. Engin, O. Erdem. Eur J. Radiol. 77(3) (2011) 468-472.

18. Y. Hirokawa, H. Isoda, Y.S. Maetani, S. Arizono, K. Shimada, T. Okada, T. Shibata, K. Togashi. Radiology 251(2) (2009) 388-397.

19. M.R. Loebinger, P.G. Kyrtatos, M. Turmaine, A.N. Price, Q. Pankhurst, M.F. Lythgoe, S.M. Janes. Cancer Res. 69(23) (2009) 8862-8867.

20. M. Rief, M. Wagner, T. Franiel, V. Bresan, M. Taupitz, C. Klessen, B. Hamm, P. Asbach. Magn. Reson. Med. 27(9) (2009) 1223-1229.

21. L.P. Nucci, H.R. Silva, V. Giampaoli, J.B. Mamani, M.P. Nucci, L.F. Gamarra. Stem Cell Res. Ther. 6(1) (2015) 27. 
22. M. Ramos-Gomez, E.G. Seiz, A. Martinez-Serrano. J. Nanobiotechnol. 13(1) (2015) 20.

23. L. Kostura, D.L. Kraitchman, A.M. Mackay, M.F. Pittenger, J.W. Bulte. NMR Biomed. 17(7) (2004) 513-517.

24. E. Farrell, P. Wielopolski, P. Pavljasevic, S. van Tiel, H. Jahr, J. Verhaar, H. Weinans, G. Krestin, F.J. O'Brien, G. van Osch, M. Bernsen. Biochem. Biophys. Res. Commun. 369(4) (2008) 1076-1081.

25. R. Schafer, M. Ayturan, R. Bantleon, R. Kehlbach, G. Siegel, J. Pintaske, S. Conrad, H. Wolburg, H. Northoff, J. Wiskirchen, R. Weissert. Cell Transplant. 17(8) (2008) 923-941.

26. R. Schafer, R. Kehlbach, M. Müller, R. Bantleon, T. Kluba, M. Ayturan, G. Siegel, H. Wolburg, H. Northoff, K. Dietz, C.D. Claussen, J. Wiskirchen. Cytotherapy 11(1) (2009) 68-78.

27. R. Schafer, R. Bantleon, R. Kehlbach, G. Siegel, J. Wiskirchen, H. Wolburg, T. Kluba, F. E ibofner, H. Northoff, C.D. Claussen, H.P. Schlemmer. BMC Cell Biol. 11 (2010) 22.

28. D.M. Huang, J.K. Hsiao, Y.C. Chen, L.Y. Chien, M. Yao, Y.K. Chen, B.S. Ko, S.C. Hsu, L.A. Tai, H.Y. Cheng, S.W. Wang, C.S. Yang, Y.C. Chen. Biomaterials 30(22) (2009) 3645-3651.

29. Y.C. Chen, J.K. Hsiao, H.M. Liu, I.Y. Lai, M. Yao, S.C. Hsu, B.S. Ko, Y.C. Chen, C.S. Yang, D.M. Huang. Toxicol. Appl. Pharmacol. 245(2) (2010) 272-279.

30. Y.K. Chang, Y.P. Liu, J.H. Ho, S.C. Hsu, O.K. Lee. J. Orthop. Res. 30(9) (2012) 1499-1506.

31. B. Novotna, P. Jendelova, M.Kapcalova, P.Jr. Rossner, K. Turnovcova, Y. Bagryantseva, M. Babic, D. Horak, E. Sykova. Toxicol. Lett. 210(1) (2012) 53-63.

32. V. Diana, P. Bossolasco, D. Moscatelli, V. Silani, L. Cova. PLoS One 8(11) (2013) e78435.

33. Z. Huang, C. Li, S. Yang, J. Xu, Y. Shen, X. Xie, Y. Dai, H. Lu, H. Gong, A. Sun, J. Qian, J. Ge. Int. J. Nanomed. 10 (2015) 1679-1690.

34. E. Bull, S.Y. Madani, R. Sheth, A. Seifalian, M. Green, A.M. Seifalian. Int. J. Nanomed. 9 (2014) 1641-1653.

35. R. Guzman, N. Uchida, T.M. Bliss, D. He, K.K. Christopherson, D. Stellwagen, A. Capela, J. Greve, R.C. Malenka, M.E. Moseley, T.D. Palmer, G.K. Steinberg. Proc. Natl. Acad. Sci. USA 104(24) (2007) 10211-10216.

36. A.S. Arbab, S.D. Pandit, S.A. Anderson, G.T. Yocum, M. Bur, V. Frenkel, H.M. Khuu, E.J. Read, J.A. Frank. Stem Cells 24(3) (2006) 671-678.

37. Y. Loai, N. Sakib, R. Janik, W. Foltz, H.L. Cheng. Mol. Imag. 11(2) (2012) 166-175.

38. L. Faucher, A.A. Guay-Bégin, J. Lagueux, M.F. Côté, E. Petitclerc, M.A. Fortin. Contrast Media Mol. Imaging 6(4) (2011) 209-218.

39. A. Hedlund, M. Ahrén, H. Gustafsson, N. Abrikossova, M. Warntjes, J.I. Jönsson, K. Uvdal, M. Engström. Int. J. Nanomed. 6 (2011) 3233-3240.

40. N. Abrikossova, C. Skoglund, M. Ahrén, T. Bengtsson, K. Uvdal. Nanotechnology 23(27) (2012) 275101.

41. M.I. Setyawati, P.K. Khoo, B.H. Eng, S. Xiong, X. Zhao, G.K. Das, T.T. Tan, J.S. Loo, D.T. Leong, K.W. Ng. J. Biomed. Mater. Res. Part A 101(3) (2013) 633-640.

42. Y. Jin, S. Chen, J. Duan, G. Jia, J. Zhang. J. Inorganic Biochem. 146 (2015) 28-36. 
43. S.B. Brijmohan, S. Swier, R.A. Weiss, M.T. Shaw. Ind. Eng. Chem. Res. 44 (2005) 8039-8045.

44. A. Tautzenberger, S. Lorenz, L. Kreja, A. Zeller, A. Musyanovych, H. Schrezenmeier, K. Landfester, V. Mailänder, A. Ignatius.

Biomaterials 31(8) (2010) 2064-2071.

45. C. Loos, T. Syrovets, A. Musyanovych, V. Mailänder, K. Landfester, G.U. Nienhaus, T. Simmet. Beilstein J. Nanotechnol. 5 (2014) 2403-2412.

46. I. Brustle, T. Simmet, G.U. Nienhaus, K. Landfester, V. Mailänder. Beilstein J. Nanotechnol. 6 (2015) 383-395.

47. $\quad$ E. Akhan, D. Tuncel, K.C. Akcali. BioMed Res. Int. 2015 (2015) 298430.

48. A.P. Alivisatos. Science 271 (1996) 933-937.

49. W.C. Chan, S. Nie. Science 281 (1998) 2016-2018.

50. J. Yao, D.R. Larson, H.D. Vishwasrao, W.R. Zipfel, W.W. Webb. Proc. Natl. Acad. Sci. USA 102(40) (2005) 14284-14289.

51. J.R. Slotkin, L. Chakrabarti, H.N. Dai, R.S. Carney, T. Hirata, B.S. Bregman, G.I. Gallicano, J.G. Corbin, T.F. Haydar. Dev. Dynam. 236(12) (2007) 3393-3401.

52. S. Danner, H. Benzin, T. Vollbrandt, J. Oder, A. Richter, C. Kruse. Int. J. Cell Biol. 2013 (2013) 918242.

53. S.H. Hsu, Y.Y. Lin, S. Huang, K.W. Lem, D.H. Nguyen, D.S. Lee. Nanotechnology 24(47) (2013) 475102.

54. M.C. Collins, Gunst P.R., B.J. Muller-Borer. Methods Mol. Biol. 1199 (2014) 141-154.

55. Y.S. Kim, J,Y. Kim, D.M. Shin, J.W. Huh, S.W. Lee, Y.M. Oh. Tuberc. Respir. Dis. (Seoul) 77(3) (2014) 116-123.

56. W. Shang, X. Zhang, M. Zhang, Z. Fan, Y. Sun, M. Han, L. Fan. Nanoscale 6(11) (2014) 5799-5806.

57. X. Wen, Y. Wang, F. Zhang, X. Zhang, L. Lu, X. Shuai, J. Shen. Biomaterials 35(16) (2014) 4627-4635.

58. Y.W. Wang, K. Yang, H. Tang, D. Chen, Y.L. Bai. Int. J. Nanomed. 9 (2014) $4809-4817$.

59. X. Wu, F. Tian, J.X. Zhao, M. Wu. Expert Opin. Drug Metab. Toxicol. 9(10) (2013) 1265-1277.

60. W.H. Chan, N.H. Shiao. Acta pharmacologica Sinica 29(2) (2008) 259-266.

61. M. Ema, N. Kobayashi, M. Naya, S. Hanai, J. Nakanishi. Reproduct. Toxicol. 30(3) (2010) 343-352.

62. T. Amna, H. Van Ba, M. Vaseem, M.S. Hassan, M.S. Khil, Y.B. Hahn, H.K. Lee, I.H. Hwang. Appl. Microbiol. Biotechnol. 97(12) (2013) 5545-5553.

63. T. Liu, R. Xing, Y.F. Zhou, J. Zhang, Y.Y. Su, K.Q. Zhang, Y. He, Y.H. Sima, S.Q. Xu. Biomaterials 35(9) (2014) 2942-2951.

64. L. Accomasso, E. Cibrario Rocchietti, S. Raimondo, F. Catalano, G. Alberto, A. Giannitti, V. Minieri, V. Turinetto, L. Orlando, S. Saviozzi, G. Caputo, S. Geuna, G. Martra, C. Giachino. Small 8(20) (2012) 3192-3200.

65. A.E. Garcia-Bennett, M. Kozhevnikova, N. König, C. Zhou, R. Leao, T. Knöpfel, S. Pankratova, C. Trolle, V. Berezin, E. Bock, H. Aldskogius, E.N. Kozlova. Stem Cells Transl. Med. 2(11) (2013) 906-915.

66. D. Bocking, O. Wiltschka, J. Niinimäki, H. Shokry, R. Brenner, M. Lindén, C. Sahlgren. Nanoscale 6(3) (2014) 1490-1498. 
67. K. Fujioka, S. Hanada, Y. Inoue, K. Sato, K. Hirakuri, K. Shiraishi, F. Kanaya, K. Ikeda, R. Usui, K. Yamamoto, S.U. Kim, Y. Manome. Int. J. Mol. Sci. 15(7) (2014) 11742-11759.

68. E. Izak-Nau, K. Kenesei, K. Murali, M. Voetz, S. Eiden, V.F. Puntes, A. Duschl, E. Madarász. Nanotoxicology 8(1) (2014) 138-148.

69. K.J. Kim, Y.A. Joe, M.K. Kim, S.J. Lee, Y.H. Ryu, D.W. Cho, J.W. Rhie. Int. J. Nanomed. 10 (2015) 2261-2272.

70. V.S. Periasamy, J. Athinarayanan, A.A. Akbarsha, A.A. Alshatwi. Appl. Biochem. Biotechnol. 175(2) (2015) 1181-1192. 


\section{Chapter 24}

